\title{
Empirical Study of Impact of Promotion of Store Brands (Private Labelled) in Chain Stores in Pakistan
}

Bilal Yaseen*

University of Central Punjab, Lahore, Pakistan

\begin{abstract}
Introduction: Store brands also known as private labelled brands have tremendous role in the retailing business boost in Pakistan. This paper aims at the study of the impact of promotional activities, done by the local chain stores in Pakistan; to make their in-store brands aware. This study is important regarding the understanding of private label brands. It studies the buyer views on private labels. This research study aims to know the extent to which store brands are promoted by the retailers. It has been found that promotion of store brand has not been done on large scale level in Pakistan.
\end{abstract}

Purpose of study: a) To understand impact of promotion of store brands in retail chain stores of Pakistan. b) The extent to which store brands have been promoted. c) Either they are promoted or not? d) If yes than what are the promotional activities been adopted by the retailers.

Method design and sample: Quantitative research, descriptive statistics, convenient sampling.

Results: After conducting the survey and applying the data empirically it has been found that store brands are promoted less as compared to national brands in Pakistan. The promotion of store brands is done only within the stores only.

Managerial implications: This article throw some light on the literature of store brands and their contribution to the success of local stores. Further it tells about the customers buying trend toward the store brands.

Keywords: Store brands (private labelled); Promotion mix; Consumer choice; National brands

\section{Introduction}

Retail markets in Pakistan grew unexpectedly in last two decades that leads to a confused consumer at the end. Consumers are more disorganized because there are number of retailers available in the market having a tight competition [1]. While deciding about the purchase consumer is more concerned about the quality of product, its variety, place of brand among competitors, brand image and brand loyalty. Private label brands are a new scheme retailer using to target the maximum share of retail market, and to secure a better position in consumer's awareness towards a brand.

Store brands known as private labelled brands, own labelled brands, retailer's brand or house brands. These are the brands maintained by the retailers not by the manufacturers [2]. Store label branding is trending concept in the literature of retailing for last two decades. In Pakistan the growth of store brands is making the retailing a little bit complex for consumer [3,4]. The concept of departmental retailing has flourished the concept of store brands in Pakistan as it helps the stores to build loyalty among consumers by the store brands which are exclusively available at these stores [5].

The lower level of prices of store brands is the key of popularity of these brands over national (manufacturer's brands). This is the main reason of emergence of private brands in many countries since nineteenth century [6].

In this research study the impact of promotion on private label brands in Pakistan is studied. Market of Lahore has been targeted for this study. Further Metro Cash \& Carry, Hyper star, CSD, HKB, AlFatah have been selected for this study [7]. The impact of promotion on the sale of store brand in Pakistan is studied empirically in this research. As customers are shifting towards private labelled brands from national brands, it is being studied here that what influence them for that [8]. The specific Promotional acts of retailers are studied that fascinate the consumers to change their buying behaviours towards private labelled brand rather than national [9]. Store brand promotion is an important aspect that has been discussed in this research as the consumers purchase different products from their retailer but did not know for the years that whether they are using a private label brand or a national brand, thus they could form a wrong perception about retailer [10]. And the research also identifies the aspects that when a customer chooses to shop at a retailer, are there any products offered by retailer is the concern of customer or are there any other reasons that built the trust in consumer's mind [9]. There are many reasons for launching the private label brands [11].

Some of them are:

- Low dependency on national brands and promote the private label brands

- Prices are also another factor which is being considered by the customers

- A retailer is recognized by the own brand

- Domestic market will grow

*Corresponding author: Bilal Yaseen, University of Central Punjab, Lahore Pakistan, E-mail: bilalyaseen@ucp.edu.pk

Received June 07, 2018; Accepted October 05, 2018; Published October 15 2018

Citation: Yaseen B (2018) Empirical Study of Impact of Promotion of Store Brands (Private Labelled) in Chain Stores in Pakistan. J Account Mark 7: 296. doi 10.4172/2168-9601.1000296

Copyright: ( 2018 Yaseen B. This is an open-access article distributed under the terms of the Creative Commons Attribution License, which permits unrestricted use, distribution, and reproduction in any medium, provided the original author and source are credited. 
- Availability of the product to the end consumer

- Less influence of the giant national brands and their wholesalers

So, by keeping in mind the retailers are trying to launch the private label brands [12]. For these steps we have conducted the research to identify the market response, retailer's intents, consumer's observations and market directions about promotion of store brands [13]. So, we have seen that different variables are impacting promotion of private label brands directly or in-directly [14].

\section{Literature Review}

An important development in the retailing industry is the emergence of private labelled brands. Still but the level of diffusion differs extensively across nations and industries [15]. It has been found by Jag Mohan et al., that the introduction of private brands increased the retailer's profit if there is a cross-price competition among national brands is high [16].

Private label brands are products which have been tactfully branded by a retailer underneath the one name of brand [1]. They are also known as house brands, store brands or retailer's brand. They are different because they are available exclusively on retail stores. The retailer decides about its production, packing and marketing to develop the relationship of loyalty between the products and the consumer [17]. Private label brands are usually inexpensive than national brands because the retailers manage production of the brands to match customer's demand and lessen advertising expenses [18].

Researchers have found that the advertising campaign of national brands only bring the consumer to the store. While the store brands sold by the retailers and more profit is gained through them. This fact has created a spurt in the literature of retailing on the topic of promotion of store brands as compared to the national brands [19].

Pool, 2009 stated that store branding means a large distribution channels (retailer) buy from a manufacturer in large quantity and puts the products on shelf with their own name on the products. This strategy is normally only profitable when the sales capacity is high. Also defined the advantages a retailer can have by promoting private brands like more independence and elasticity in pricing, controlling product characteristics and quality, eradicates producer's promotional costs. Some advantages to the manufacturer are like reduced promotional costs, stability of sales volume (at least while the contract is operative), increase production capacity if not currently running at $100 \%$, can grow smaller local businesses as retailer would prefer using nonNational Branded manufacturers. A well promoted store brand can be a strategic tool for a retailer to generate greater larger market share. The presence of a store brand also affects the ability of the store to compete against its rival stores. Private store brands have an advantage over the national brands as the manufacturer have platform of activity; the retailing shops. They can directly hear the view of shoppers which lay the base for a true store brand. Price is another factor that is why customer preference to store brands over national brands. But the packing quality of brands is low which is due to low cost motive. This low standard packing has trade-off with the quality of products [20]. The slumps in economic conditions compel the consumer towards the store brands as well and this could be considered as the initiating factor. But once consumer realizes the price and quality of product, they understand that the quality of product is very much according to the price and no compromise has been made on it. Retailers also prefer to shift the national brands with the store brands [4]. Customers no longer view private label/store label as a trade-down and, more often, see private label as just another branded option8. Example: POONAM Rice of IMTIAZ and Metro's 'OK and Fine Food Brands'.

\section{Research Methodology}

\section{Problem statement}

The study deals with impact of promotion of store brands in Pakistan's retail markets. The retailer desires to understand consumer's approach, their beliefs and attitude towards In Store brands which can help retailers in better promotional and designing marketing strategies to accelerate sales of their store brands [21-23].

\section{Objective of the study}

1. To understand impact of promotion of store brands in retail chain stores of Pakistan.

2. The extent to which store brands have been promoted.

3. Either they are promoted or not?

4. If yes than what are the promotional activities been adopted by the retailers.

\section{Conceptual framework}

The conceptual framework is described by Figure 1 below. The theoretical framework attempts to explain the research problem. In this research the relationship of promotion of store brands done by the retailers and awareness of store brands among the consumers is studied.

\section{Variables of study}

Independent variables for the study are sales promotion, advertising, direct marketing. While dependent variable is promotion of store brands.

Sales promotion is defined as a special offer or a part of marketing communication activities. Other studies defined sales promotion as an offer or incentive that induces manufacturers, and retailers, desired sales result.

Advertising means the paid presentation and promotion concepts of ideas, programs or services in magazines, newspapers, radio transmission, billboards, email, social media and many more [24].

Direct marketing involves the sharing of information regarding special offers, products, sales announcements, reminders and other types of announcement to a person at a street or electronic address. Direct marketing involves a wide range of marketing materials for example brochure, catalogue, postcard, newsletter, and sales letter (Figure 2) [25-27].

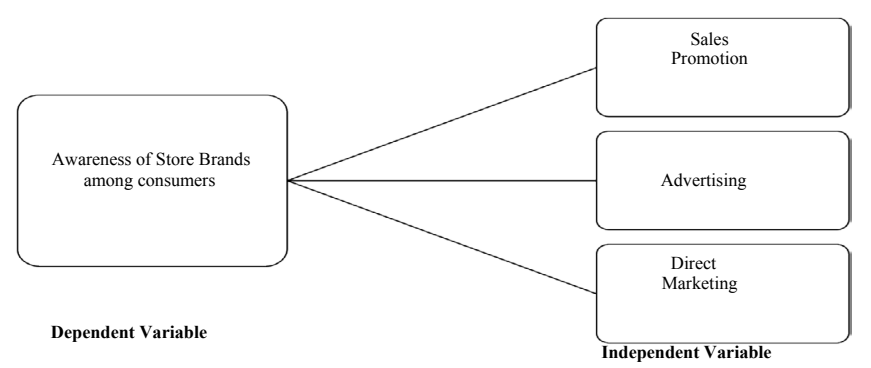

Figure 1: Theoretical framework. 
Citation: Yaseen B (2018) Empirical Study of Impact of Promotion of Store Brands (Private Labelled) in Chain Stores in Pakistan. J Account Mark 7: 296. doi: 10.4172/2168-9601.1000296

Page 3 of 4

\section{Theoretical framework}

Hypotheses: H1: Customers get aware of store brands by retailers through direct marketing; H2: Store brands are promoted by the retailers; H3: Customers get aware of store brands retailers through sales promotion activities; H4: Customers get aware of store brands by retailers through advertisement (Figure 3).

Methodology:

1. Research design: The chosen research design was Descriptive Cross-Sectional Study as well as Quantitative Research Study:

2. Sources of data: Primary Data

3. Data collection technique: Survey

4. Data collection tool: Questionnaire (attached) (Figure 4).

\section{Respondents}

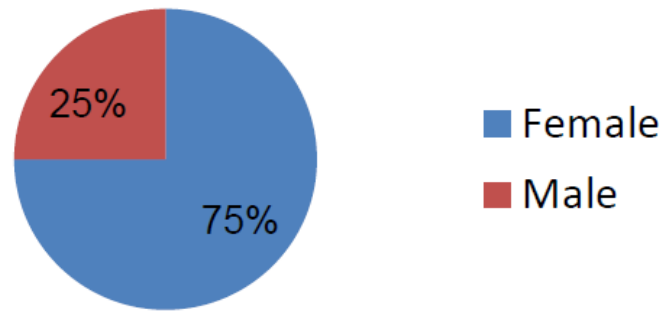

Figure 2: Respondents.
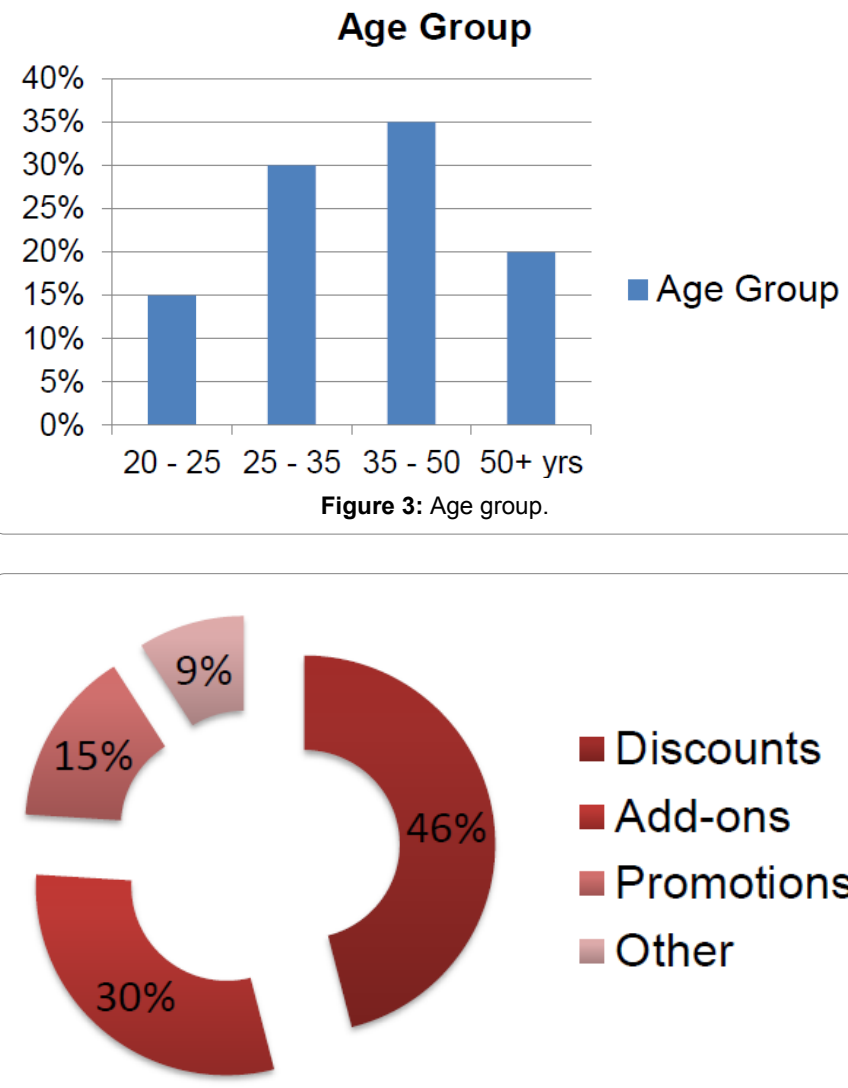

- Discounts

Add-ons

- Promotions

Other

Figure 4: Factors that can help induce in-house brand

\section{Sample design:}

- Sample procedure: Convenience Sampling

- Sample frame: The respondents were working professionals \& house wives between the age group of 25-50 years.

- Sample size: The study was conducted based on sample size of 20 .

\section{Findings}

- After conducting the survey and applying the data empirically it has been found that store brands are promoted less as compared to national brands in Pakistan.

- The promotion of store brands is done only within the stores only.

- Further discount rates are offered on store brands which is an element of sales promotion.

- Consumer is aware of store brands in Pakistan.

\section{Limitations of the Study}

- The customers' study was conducted only in Lahore city. The results of the study are limited to this area only and are not necessarily applicable to the other areas.

- The sample size selected for the survey of the customers as well as retailers was small, so it will be difficult to generalize the findings of study.

- Biased views of respondents are there so results cannot be accurate.

- In the questionnaire, questions are close ended and are of objective nature.

\section{References}

1. Srivastava $R$, Singhal $A$, Raghavi $P$, Khandelwal $M$, Balasubramanian $S$, et al (2005) Brands Equity of Toothpaste Brands in India. Ind J Mark 35.

2. Ashley S R (1998) How to effectively compete against private-label brands. J Advert Res 38: 75-83.

3. Beneke $\mathrm{J}$ (2010) Consumer perceptions of private label brands within the retail grocery sector of South Africa. Afr J Bus Manage 4: 203.

4. Wu P C, Yeh GYY, Hsiao CR (2011) The effect of store image and service quality on brand image and purchase intention for private label brands. Aust Mark J 19: 30-39.

5. Baltas $\mathrm{G}$ (2003) A combined segmentation and demand model for store brands Eur J Mark 10: 1499-1513.

6. Jin B, Gu Suh $Y$ (2005) Integrating effect of consumer perception factors in predicting private brand purchase in a Korean discount store context. J Consum Mark 22: 62-71.

7. Herstein R, Jaffe ED (2007) Launching store brands in emerging markets: resistance crumbles. J Bus Strat 28: 13-19.

8. Walsh G, Mitchell VW (2010) Consumers' intention to buy private label brands revisited. J Gen Manage 35: 3-24.

9. Chinomona R, Dubihlela D (2014) Does customer satisfaction lead to customer trust, loyalty and repurchase intention of local store brands? The case of Gauteng Province of South Africa. Mediterr J Soc Sci 5: 23.

10. Vaidyanathan R, Aggarwal P (2000) Strategic brand alliances: implications of ingredient branding for national and private label brands. J Prod Brand Manage 9: $214-228$.

11. Richardson P, Jain AK, Dick A (1996) The influence of store aesthetics on evaluation of private label brands. J Prod Brand Manage 5: 19-28.

12. Ailawadi KL, Harlam BA, César J (2006) Promotion profitability for a retailer: 
Citation: Yaseen B (2018) Empirical Study of Impact of Promotion of Store Brands (Private Labelled) in Chain Stores in Pakistan. J Account Mark 7: 296. doi: 10.4172/2168-9601.1000296

Page 4 of 4

the role of promotion, brand, category, and store characteristics. J Mark Res 43: 518-535.

13. Bao Y, Bao Y, Sheng S (2011) Motivating purchase of private brands: Effects of store image, product signatureness, and quality variation. J Bus Res 64: 220-226.

14. Chandon P, Hutchinson JW, Bradlow ET, Young SH (2009) Does in-store marketing work? Effects of the number and position of shelf facings on brand attention and evaluation at the point of purchase. J Mark 73: 1-17.

15. Benedict J, Steenkamp E (1997) The increasing power of store brands: Building loyalty and market share. Long Range Planning 30: 917-930.

16. Garretson JA, Fisher D, Burton S (2002) Antecedents of private label attitude and national brand promotion attitude: similarities and differences. J Retailing 78: 91-99.

17. Batra R, Sinha I (2000) Consumer-level factors moderating the success of private label brands. J Retailing 76: 175-191.

18. Baltas G, Doyle P, Dyson $P$ (1997) A model of consumer choice for national vs. private label brands. J Oper Res Soc 48: 988-995.
19. Chevalier M (2012) Luxury Brand Management. John Wiley \& Sons, Singapore.

20. Pool $L$ (2009) There's new appetite for peddlers of cheap eats. Boston Business Journal. Private Label Trends Worldwide.

21. Sayman S, Raj J (2003) How category characteristics affect the number of store brands offered by the retailer: a model and empirical analysis. J Retailing

22. Bonfrer A, Chintagunta PK (2003) Store brands: Who buys them and what happens to retail prices when they are introduced? Int J Mark 24: 195-218.

23. Ahmed S (2016) Retail in Pakistan - An Overview.

24. Nisar W (2014) Influences of Consumer Behaviour: Research about Beverage Brands of Pakistan. Int J Acad Res Bus Soc Sci 4: 137

25. Clark W (1960) Clark's oxidation reduction potentials of organic systems. J Phys Chem 38: 158.

26. Stone B, Jacobs R (1988) Successful direct marketing methods: NTC Business Books Lincolnwood, IL.

27. Chiang W, Chhajed D, Hess JD (2003) Direct marketing, indirect profits: A strategic analysis of dual-channel supply-chain design. Manage Sci 49: 1-20. 